\title{
Sistem Informasi Klinik Hewan Untuk Meningkatkan Kinerja Keuangan Menggunakan Metode Rasio Profitabilitas
}

\author{
Taufik Kurnialensya \\ Univ.STEKOM, Fakultas Komputer dan Bisnis, Semarang, Indonesia \\ taufik@stekom.ac.id
}

Diterima 27 April 2021

Disetujui 14 Juni 2021

\begin{abstract}
Veterinary Clinic XZY Semarang is an agency engaged in serving its clients in caring for the health of livestock and pets. In recording and processing data using an organized system and not yet well integrated. In financial management and also in making financial reports, it is not optimal in evaluating financial performance, so that they cannot see the ability to generate operating profit from the income generated. There is a need for a system to be used to increase activity at the veterinary clinic, so that it is much more effective and efficient in the provision of equipment, equipment, and data management including recording, making financial reports, and assessing financial performance, so that it can show the time used and the system as well. can be accessed simultaneously by interested parties. In the implementation of a new system, namely the Animal Clinic Information System to Improve Financial Performance with the Web-Based Ratio method. From these problems, an application program can be made using php program and MySQL as the database. With the above design, it provides benefits for veterinary clinics that provide benefits in improving their financial performance, can be accessed simultaneously, and provides services in the provision of equipment and equipment needed.
\end{abstract}

Index Terms-Ratio Method Profitabilitas, Animal Clinic, Information System.

\section{Pendahuluan}

Pengembangan sebuah teknologi memiliki tujuan untuk menaikkan produktivitas dan efektivitas pengguna baik dari SDM maupun organisasi. Perkembangan dalam penggunaan teknologi berbasis web sangat berguna bagi perusahaan atau instansi. Web merupakan sebuah teknologi yang mana pemakai dapat menjalankan secara bersamaan dari satu atau lebih hardware, software, dan informasi [2].

Perusahaan atau instansi harus mampu berkontribusi didalam membagi informasi, juga bentuk keterangan akan semua proses kegiatan perusahaan yang dikerjakan dalam kurun waktu tertentu, yang mana keterangan itu berkaitan dengan kinerja atau keuangan kepada pimpinan perusahaan[4].
Dalam melakukan sebuah penilaian terhadap kegiatan keuangan dalam perusahaan adalah dengan memakai sebuah analisis rasio probalitas. Penilaian ini biasanya digunakan untuk mengetahui produktifitas dari suatu perusahaan atau instansi [7]. Tingkat profitabilitas perusahaan yang tinggi menunjukkan kemampuan suatu perusahaan atau instansi dalam menciptakan laba atau keuntungan [6].

Klinik Hewan XYZ Semarang merupakan instansi yang bergerak dibidang jasa melayani kliennya dalam merawat kesehatan hewan ternak ataupun hewan peliharaan. Dalam pencatatan dan pengolahan data belum menggunakan sistem yang terorganisasi dan terintegrasi dengan baik, karena dalam masih menggunakan Microsoft Office dalam pengelolaan data.

Dalam sistem ini kurang maksimal pengerjaannya, membutuhkan waktu yang lama dan tingkat kesalahan penginputannya sangat besar, sehingga informasi yang didapatkan tidak akurat atau tidak maksimal. Seringkali bentuk laporan yang disajikan mengalami kesulitan didalam menginterprestasikan terutama yang berkaitan laporan keuangan. Padahal laporan keuangan merupakan manifestasi dari aktivitas yang harus dipertanggung jawabkan [9].

Dalam pengelolaan keuangan dan juga dalam pembuatan laporan keuangan kurang maksimal didalam melakukan evaluasi terhadap kinerja keuangan, sehingga tidak dapat diketahui seberapa besar dan kecil nilai laba pendapatan yang dihasilkan dari sebuah perusahaan. Salah satu cara untuk menilai efisiensi kinerja keuangan dari suatu usaha dalam manajemen keuangan adalah dengan menggunakan analisis rasio profitabilitas. Penilaian profitabilitas ini menggunakan beberapa kriteria antara lain : Net Profit Margin dan Return On Assets.

Net Profit Margin merupakan Rasio yang menggambarkan besarnya laba bersih yang diperoleh oleh perusahaan pada setiap penjualan yang dilakukan, dengan rumus laba bersih dibagi penjualan bersih.

Return On Asset merupakan Rasio yang menggambarkan kemampuan perusahaan untuk menghasilkan keuntungan dari setiap satu rupiah aset 
yang digunakan, dengan rumus laba bersih dibagi total aktiva.

Perlu adanya sistem yang digunakan dapat meningkatkan aktivitas pada klinik hewan tersebut, sehingga jauh lebih baik, tepat, dan cermat dalam mempersiapkan perlengkapan, peralatan, dan pengolahan datanya yang meliputi pencatatan, pembuatan laporan keuangan, serta menilai kinerja keuangannya, sehingga dapat meminimalkan waktu yang digunakan dan sistem juga dapat diakses secara bersamaan oleh pihak yang berkepentingan.

Dalam penerapan sebuah sistem yang baru yaitu Sistem Informasi Klinik Hewan Untuk Meningkatkan Kinerja keuangan Menggunakan Metode Rasio Profitabilitas memiliki tujuan sebagai berikut :

1. Menghasilkan sistem informasi klinik hewan yang digunakan untuk menganalisa laporan keuangan sehingga menghasilkan penilaian kinerja keuangan secara valid pada klinik hewan XYZ Semarang.

2. Menciptakan sistem informasi akuntansi pendapatan keuangan yang efektif serta efisien pada klinik hewan XYZ Semarang. Hal tersebut ditandai dengan:

a. Memudahkan mengevaluasi kinerja keuangan pada klinik hewan XYZ, sehingga dapat mengetahui kemampuan dalam menghasilkan laba operasi melalui pendapatan operasi yang dihasilkan.

b. Aplikasi dapat diakses secara bersamaan oleh Administrasi, Apoteker, dan Pimpinan sehingga dapat dengan mudah mengakses laporan yang dibutuhkan.

Mempermudah dalam penyediaan perlengkapan dan peralatan yang dibutuhkan, serta memberikan kemudahan dalam pengolahan datanya, sehingga dapat meminimalkan waktu yang digunakan

\section{TinjauAn Pustaka}

\section{A. Sistem Informasi}

Sistem informasi adalah sebuah unsur yang memiliki keterkaitan didalam kinerja berdasarkan langkah-langkah yang berhubungan, dan saling mempengaruhi dengan satu dan lainnya dengan tujuan menghasilkan sesuatu.

Komponen sistem informasi diklasifikasikan sebagai berikut : hardware dan software yang berfungsi sebagai mesin, people dan procedures yang merupakan manusia dan tatacara menggunakan mesin, Data yang merupakan jembatan penghubung antara manusia dan mesin agar terjadi suatu proses pengolahan data [5].

\section{B. Flowchart}

Flowchart merupakan simbol yang memiliki fungsi untuk menjelaskan langkah demi langkah didalam
Flowchart adalah bagan - bagan yang mempunyai arus yang menggambarkan langkah - langkah dalam menyudahi perkara dalam suatu hal. Flowchart dibuat menggunakan simbol. Simbol ini digunakan sebagai alat bantu untuk menampilkan proses didalam program. Simbol di dalam flowchart dapat dibedakan menjadi dua bagian, yaitu simbol petunjuk dan simbol proses [3].

\section{Akuntansi}

Akuntansi merupakan bagian dari sistem informasi yang menghitung aktifitas bisnis, mengelola data-data menjadi sebuah laporan, dan menggunakan hasilnya kepada para pengambil keputusan untuk menganalisa hasil dari sebuah laporan. Ditinjau dari sudut kegiatannya, akuntansi dapat didefinisikan sebagai "proses pencatatan, pengolahan, peringkasan, pelaporan, dan penganalisisan data keuangan suatu entitas" [1].

\section{Rasio Profitabilitas}

Rasio ini mengukur kemampuan para eksekutif perusahaan dalam menciptakan tingkat keuntungan baik dalam bentuk laba perusahaan maupun nilai ekonomis atas penjualan, aset bersih perusahaan maupun modal sendiri (shareholders equity). Rasio ini lebih diminati oleh pemegang saham dan manajemen perusahaan sebagai salah satu alat keputusan investasi, apakah investasi bisnis ini akan dikembangkan, dipertahankan, dan sebagainya [1].

\section{E. $P H P$}

PHP (Hypertext Preprocessor) adalah salah satu bahasa pemrograman berbasis web, dimana dalam pemgopersiannya membutuhkan server yang digunakan untuk mengolah data atau informasi baik itu berupaa text, gambar, suara. Bahasa pemrograman PHP ini dibuat secara gratis sehingga orang banyak menggunakan bahasa pemrograman php dibanding dengan yag lainnya [3].

\section{F. $M y S Q L$}

MySQL merupakan sebuah database server yang penggunaannya untuk membuat aplikasi berbasis web, dengan kata lain database ini sebagai induk dalam penyimpanan data atau infomasi dan pengolahan datanya. Kepopuleran MySQL antara lain karena MySQL menggunakan SQL (structure query language) sebagai bahasa dasar untuk mengakses database-nya sehingga mudah untuk digunakan, kinerja query cepat, serta mencukupi kebutuhan database [3].

\section{Metodologi PenElitian}

Borg and Gall dalam "Educational Research" (2003) menerangkan : R \& D didalam dunia pendidikan merupakan model pengembangan penelitian yang berbasis industri yang mana pengembangan penelitian digunakan dalam mendesain sebuah produk dan dengan langkah baru, setelah itu 
dilanjutkan dengan tahapan diuji dilapangan, dievaluasi, dan dilengkapi jika ada kekurangan hingga mendapatkan standar yang telah ditetapkan [8]. Langkah-langkah dalam metodologi penelitian enam langkah :

\section{A. Penelitian Pendahuluan}

Langkah pendahuluan ini yaitu melaksanakan dan melakukan penghimpunan data, dengan langkahlangkah seperti :

1. Melakukan wawancara dengan bagian yang berwenang di klinik hewan XYZ Semarang.

2. Melakukan observasi dengan cara mengamati proses kinerja pada klinik hewan XYZ Semarang dalam pembuatan laporan pendapatan.

3. Memahami kajian-kajian yang bersifat literatur dengan tujuan mendapatkan teori atau informasi lainnya sebagai bahan rujukan.

\section{B. Perencanaan}

Pada tahap ini dilakukan:

1. Merumuskan tujuan penelitian.

2. Menentukan spesifikasi produk.

3. Membuat jadwal kegiatan.

\section{Mengembangkan Bentuk Produk Awal}

Membuat perancangan atau model produk dalam bentuk rancang sistem. Hal ini difungsikan supaya didalam pengembangan aplikasi (sistem program) sebagai acuannya. Perancanngan ini meliputi Flow of documant, Data Flow Diagram, Desain Basis Data, Normalisasi, Entity Relational Diagram, tampilan pengguana yang berupa rancangan sistem yang akan dibuat.

1. Diagram Konteks

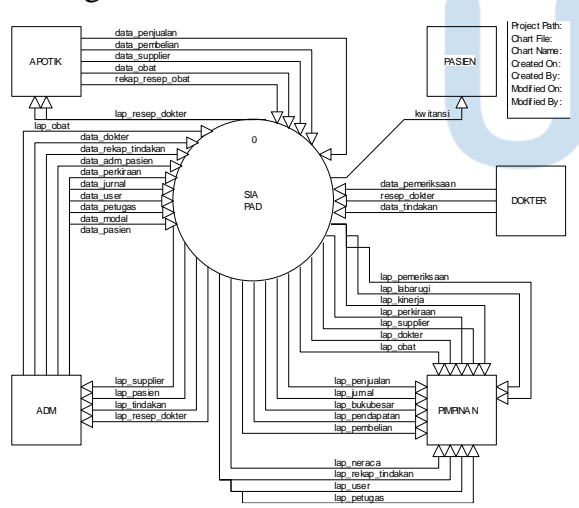

Gambar 1. Konteks Diagram
Keterangan :

- Dari entitas apotik masuk ke sistem berupa data penjualan, data pembelian, data supplier, data obat, dan rekap resep obat. Sedangkan dari sistem menerima laporan resep dokter dan laporan obat.

- Dari entitas pasien menerima laporan dari sistem berupa kwitansi.

- Dari entitas dokter masuk ke sistem berupa resep dokter, data pemeriksaan, dan data tindakan.

- Entitas adm masuk ke sistem berupa data pasien, data dokter, data petugas, data user, data rekap tindakan, data adm pasien, data perkiraan, data modal, dan data jurnal. Sedangkan dari sistem menerima laporan supplier, laporan pasien, laporan tindakan, dan laporan resep dokter.

- Dan pada entitas pimpinan menerima hasil laporan laba rugi, laporan jurnal, laporan buku besar, laporan pendapatan, laporan neraca, laporan kinerja, laporan supplier, laporan perkiraan, laporan dokter, laporan obat, laporan penjualan, laporan pembelian, laporan pemeriksaan, laporan user, laporan petugas, dan laporan rekap tindakan.

2. Normalisasi

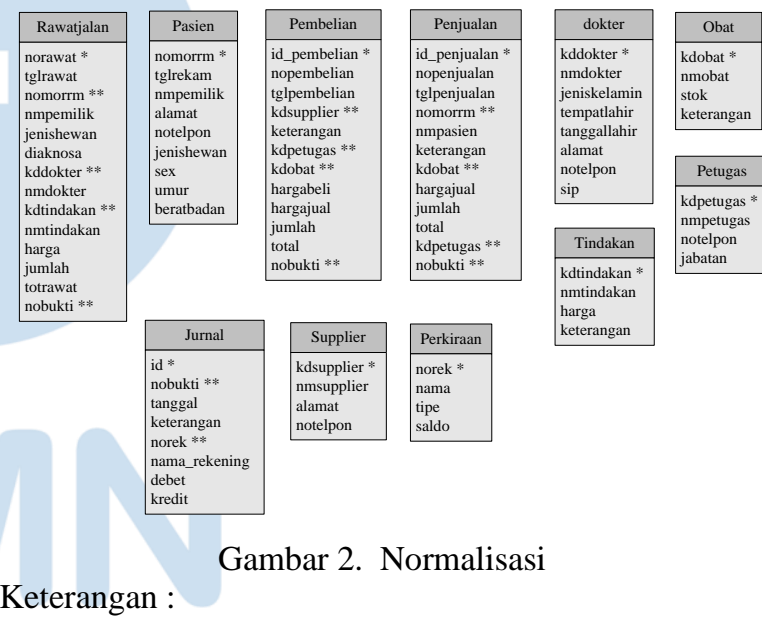

Gambar 2 menjelaskan hubungan antar tabel yang saling mempengaruhi satu dengan lainnya.

Hubungan diantara tabel wajib memiliki atribut kunci primer dan kunci sekondari pada tabel relasinya $\left(*=\right.$ Primary Key, ${ }^{*} *=$ Secondary Key $)$. 
3. ERD

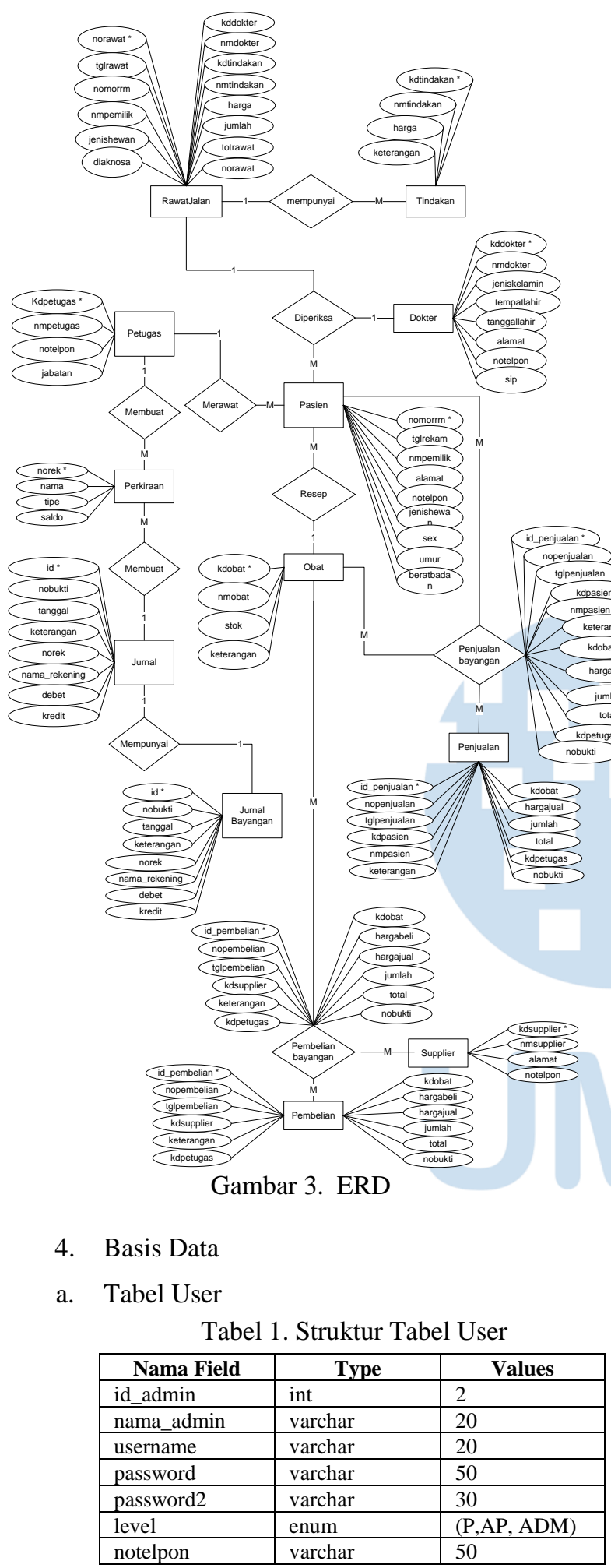

b. Tabel Petugas

Tabel 2. Struktur Tabel Petugas

\begin{tabular}{|l|c|c|}
\hline \multicolumn{1}{|c|}{ Nama Field } & Type & Values \\
\hline kdpetugas & varchar & 50 \\
\hline nmpetugas & varchar & 50 \\
\hline notelpon & varchar & 50 \\
\hline jabatan & varchar & 50 \\
\hline
\end{tabular}

c. Tabel Rawat Jalan

Tabel 3. Struktur Tabel Rawat Jalan

\begin{tabular}{|l|c|c|}
\hline \multicolumn{1}{|c|}{ Nama Field } & Type & Values \\
\hline norawat & varchar & 50 \\
\hline tglrawat & date & \\
\hline nomorrm & varchar & 50 \\
\hline nmpemilik & varchar & 50 \\
\hline jenishewan & varchar & 50 \\
\hline diaknosa & varchar & 50 \\
\hline kddokter & varchar & 50 \\
\hline nmdokter & varchar & 50 \\
\hline kdtindakan & varchar & 50 \\
\hline nmtindakan & varchar & 50 \\
\hline harga & int & 11 \\
\hline jumlah & int & 11 \\
\hline totrawat & int & 11 \\
\hline nobukti & varchar & 50 \\
\hline
\end{tabular}

d. Tabel Tindakan

Tabel 4. Struktur Tabel Tindakan

\begin{tabular}{|l|c|c|}
\hline \multicolumn{1}{|c|}{ Nama Field } & Type & Values \\
\hline kdtindakan & varchar & 50 \\
\hline nmtindakan & varchar & 50 \\
\hline harga & int & 11 \\
\hline keterangan & varchar & 50 \\
\hline
\end{tabular}

e. Tabel Dokter

Tabel 5. Struktur Tabel Dokter

\begin{tabular}{|l|c|c|}
\hline \multicolumn{1}{|c|}{ Nama Field } & Type & Values \\
\hline kddokter & varchar & 50 \\
\hline nmdokter & varchar & 50 \\
\hline jeniskelamin & varchar & 50 \\
\hline tempatlahir & varchar & 50 \\
\hline tanggallahir & varchar & 50 \\
\hline alamat & varchar & 50 \\
\hline notelpon & varchar & 50 \\
\hline sip & varchar & 50 \\
\hline
\end{tabular}

f. Tabel Pasien

Tabel 6. Struktur Tabel Pasien

\begin{tabular}{|l|c|c|}
\hline \multicolumn{1}{|c|}{ Nama Field } & Type & Values \\
\hline nomorrm & varchar & 50 \\
\hline tglrekam & date & \\
\hline nmpemilik & varchar & 50 \\
\hline alamat & varchar & 50 \\
\hline notelpon & varchar & 50 \\
\hline jenishewan & varchar & 50 \\
\hline sex & varchar & 50 \\
\hline umur & varchar & 50 \\
\hline beratbadan & varchar & 50 \\
\hline
\end{tabular}

g. Tabel Perkiraan

Tabel 7. Struktur Tabel Perkiraan

\begin{tabular}{|l|c|c|}
\hline \multicolumn{1}{|c|}{ Nama Field } & Type & Values \\
\hline norek & varchar & 50 \\
\hline nama & varchar & 50 \\
\hline tipe & varchar & 50 \\
\hline saldo & Int & 11 \\
\hline
\end{tabular}

h. Tabel Obat

Tabel 8. Struktur Tabel Obat

\begin{tabular}{|l|c|c|}
\hline \multicolumn{1}{|c|}{ Nama Field } & Type & Values \\
\hline norek & varchar & 50 \\
\hline nama & varchar & 50 \\
\hline tipe & varchar & 50 \\
\hline saldo & Int & 11 \\
\hline
\end{tabular}


ISSN 2085-4552

i. Tabel Penjualan

Tabel 9. Struktur Tabel Penjualan

\begin{tabular}{|l|c|c|}
\hline \multicolumn{1}{|c|}{ Nama Field } & Type & Values \\
\hline id_penjualan & varchar & 50 \\
\hline nopenjualan & varchar & 50 \\
\hline tglpenjualan & date & \\
\hline kdpasien & varchar & 50 \\
\hline nmpasien & varchar & 50 \\
\hline keterangan & varchar & 50 \\
\hline kdobat & varchar & 50 \\
\hline hargajual & Int & 11 \\
\hline jumlah & Int & 11 \\
\hline total & Int & 11 \\
\hline kdpetugas & varchar & 50 \\
\hline nobukti & varchar & 50 \\
\hline
\end{tabular}

j. Tabel Penjualanbayangan

Tabel 10. Struktur Tabel Penjualanbayangan

\begin{tabular}{|l|c|c|}
\hline \multicolumn{1}{|c|}{ Nama Field } & Type & Values \\
\hline id_penjualan & varchar & 50 \\
\hline nopenjualan & varchar & 50 \\
\hline tglpenjualan & date & \\
\hline kdpasien & varchar & 50 \\
\hline nmpasien & varchar & 50 \\
\hline keterangan & varchar & 50 \\
\hline kdobat & varchar & 50 \\
\hline hargajual & Int & 11 \\
\hline jumlah & Int & 11 \\
\hline total & Int & 11 \\
\hline kdpetugas & varchar & 50 \\
\hline nobukti & varchar & 50 \\
\hline
\end{tabular}

k. Tabel Jurnal

Tabel 11. Struktur Tabel Jurnal

\begin{tabular}{|l|c|c|}
\hline \multicolumn{1}{|c|}{ Nama Field } & Type & Values \\
\hline id & int & 11 \\
\hline nobukti & varchar & 50 \\
\hline tanggal & date & \\
\hline keterangan & text & \\
\hline norek & varchar & 50 \\
\hline nama_rekening & varchar & 50 \\
\hline debet & int & 11 \\
\hline kredit & int & 11 \\
\hline
\end{tabular}

1. Tabel Jurnalbayangan

Tabel 11. Struktur Tabel Jurnalbayangan

\begin{tabular}{|l|c|c|}
\hline \multicolumn{1}{|c|}{ Nama Field } & Type & Values \\
\hline id & int & 11 \\
\hline nobukti & varchar & 50 \\
\hline tanggal & date & \\
\hline keterangan & text & \\
\hline norek & varchar & 50 \\
\hline nama_rekening & varchar & 50 \\
\hline debet & int & 11 \\
\hline kredit & int & 11 \\
\hline
\end{tabular}

m. Tabel Pembelian

Tabel 12. Struktur Tabel Pembelian

\begin{tabular}{|l|c|c|}
\hline \multicolumn{1}{|c|}{ Nama Field } & Type & Values \\
\hline id_pembelian & Int & 11 \\
\hline nopembelian & varchar & 50 \\
\hline tglpembelian & date & \\
\hline kdsupplier & varchar & 50 \\
\hline keterangan & varchar & 50 \\
\hline kdpetugas & varchar & 50 \\
\hline kdobat & varchar & 50 \\
\hline hargabeli & Int & 11 \\
\hline hargajual & Int & 11 \\
\hline
\end{tabular}


muncul adalah tampilan user login. Didalam form login disini menggunakan level pengguna yaitu terdiri dari pimpinan, Apoteker, dan Administrator (sebagai super admin)

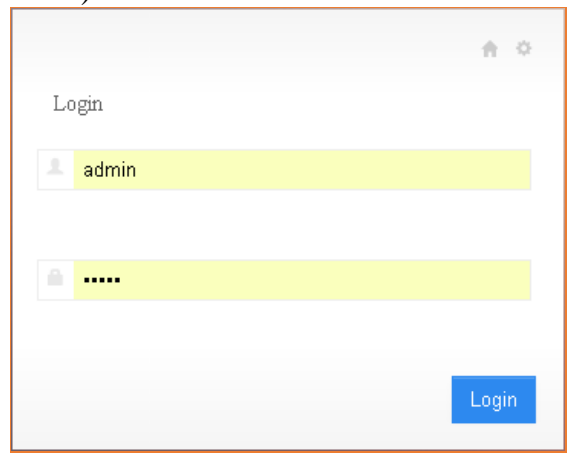

Gambar 4. Form Login

\section{B. Form User}

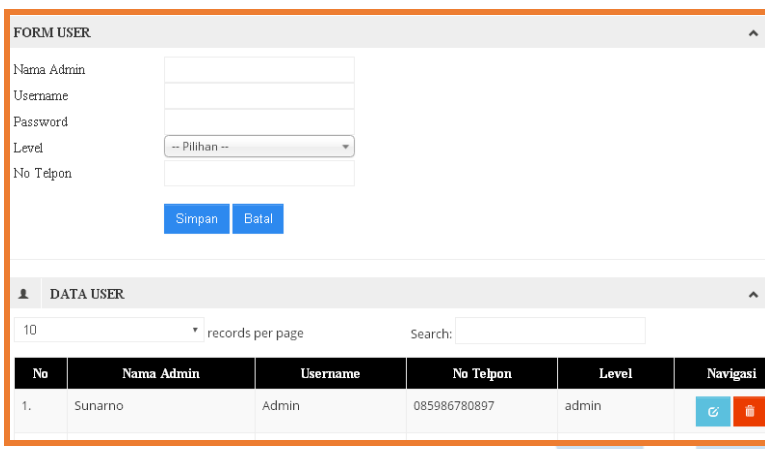

Gambar 5. Form User

Desain form user digunakan untuk memasukkan data pemakai yang terdiri dari nama admin, username, password, level, dan nomor telepon. Dibawah form user terdapat daftar data user yang digunakan untuk menampung data yang akan disimpan.

\section{Form Tindakan}

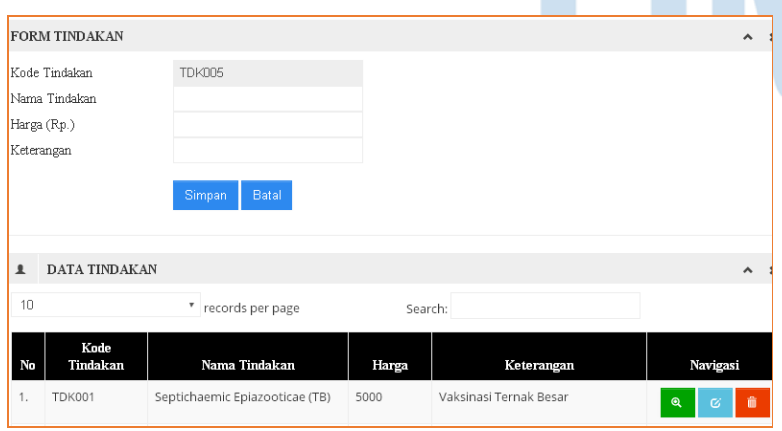

Gambar 6. Form Tindakan

Form tindakan digunakan untuk memasukkan data tindakan yang terdiri dari kode tindakan, nama tindakan, harga, dan keterangan. Dibawah form tindakan terdapat daftar data tindakan yang digunakan untuk menampung data yang akan disimpan.

\section{Form Petugas}

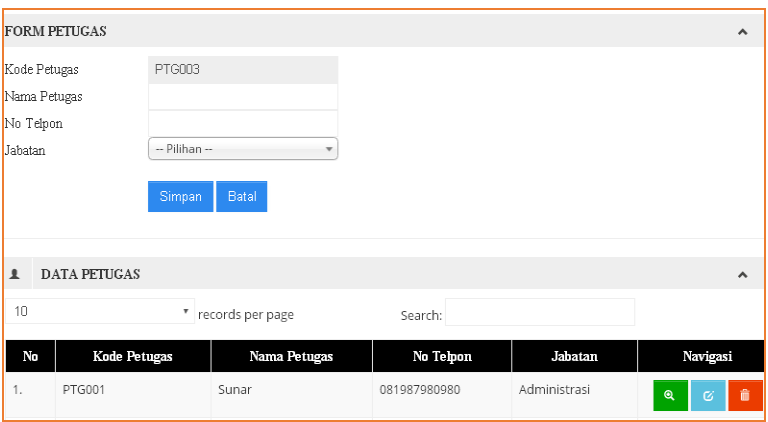

Gambar 7. Form Petugas

Form petugas digunakan untuk memasukkan data petugas yang terdiri dari kode petugas, nama petugas, nomor telpon, dan jabatan. Dibawah form petugas terdapat daftar data petugas yang digunakan untuk menampung data yang akan disimpan.

\section{E. Form Dokter}

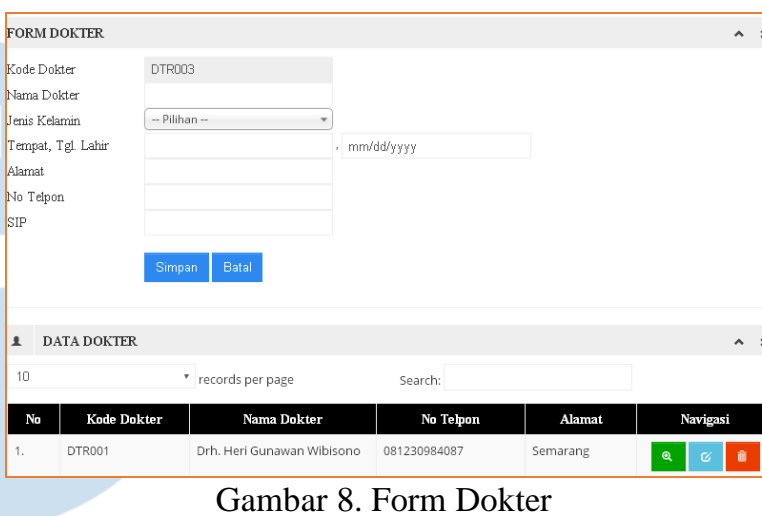

Form dokter digunakan untuk memasukkan data dokter yang terdiri dari kode dokter, nama dokter, jenis kelamin, tempat tanggal lahir, alamat, nomor telpon, dan SIP (surat ijin praktek ). Dibawah form dokter terdapat daftar data dokter yang digunakan untuk menampung data yang akan disimpan.

\section{F. Form Obat}

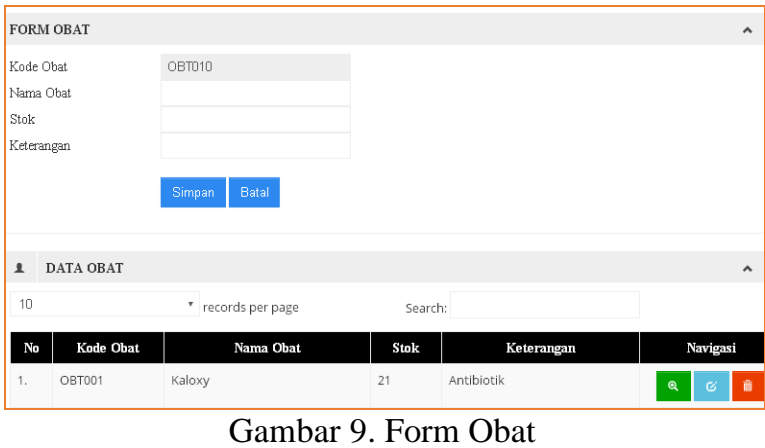

Form obat difungsikan untuk memasukkan data obat yang terdiri dari kode obat, nama obat, stok, dan keterangan. Dibawah form obat terdapat daftar data obat yang digunakan untuk menampung data yang akan disimpan. 


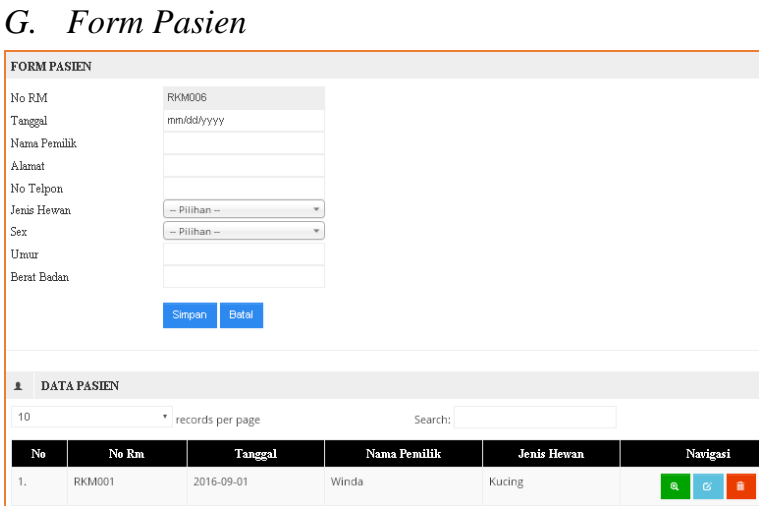

Gambar 10. Form Pasien

Form pasien digunakan untuk memasukkan data pasien yang terdiri dari nomor rekam medis (No RM), tanggal, nama pemilik, alamat, nomor telpon, jenis hewan, sex (jenis kelamin), umur, dan berat badan. Dibawah form pasien terdapat daftar data pasien yang digunakan untuk menampung data yang akan disimpan.

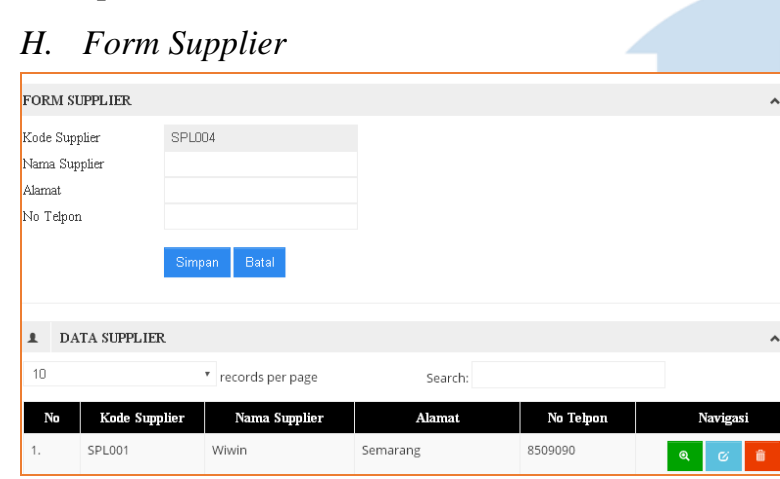

Gambar 11. Form Supplier

Form supplier digunakan untuk memasukkan data supplier yang terdiri dari kode supplier, nama supplier, alamat, dan nomor telpon. Dibawah form supplier terdapat daftar data supplier yang digunakan untuk menampung data yang akan disimpan.

\section{Form Perkiraan}

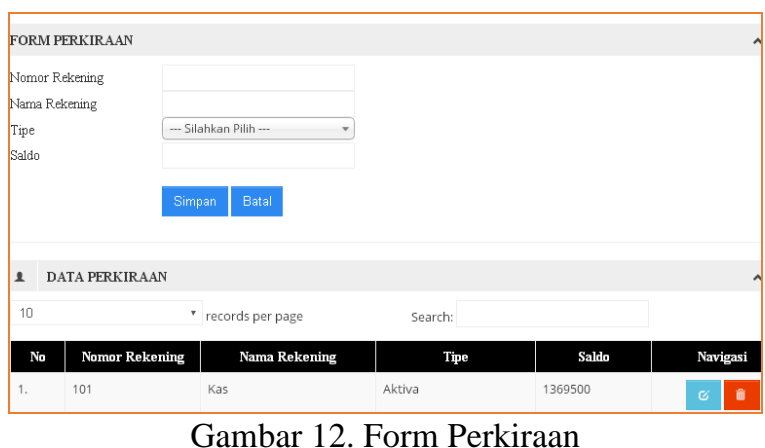

Form perkiraan digunakan untuk memasukkan data perkiraan antara lain nomor rekening, nama rekening, tipe, dan juga saldo. Dibawah form perkiraan terdapat daftar data perkiraan yang digunakan untuk menampung data yang akan disimpan.

\section{J. Form Jurnal}

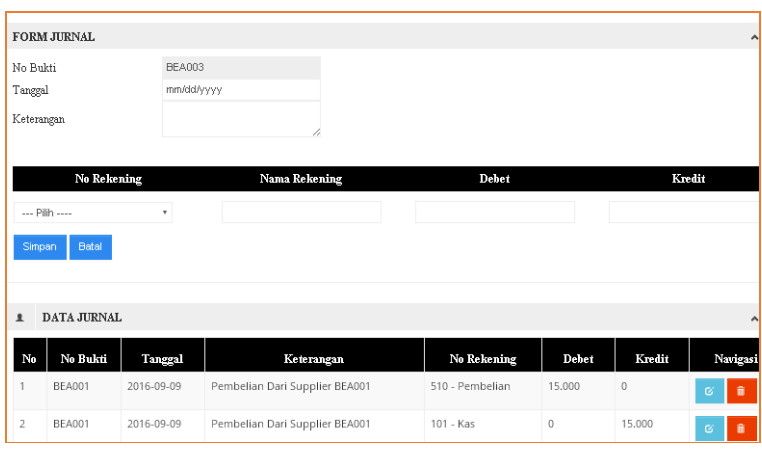

Gambar 13. Form Jurnal

Form jurnal digunakan untuk memasukkan data jurnal yang terdiri dari nomor bukti, tanggal, keterangan, nomor rekening, nama rekening, debet, dan kredit. Dibawah form jurnal terdapat daftar data jurnal yang digunakan untuk menampung data yang akan disimpan.

\section{K. Form Modal}

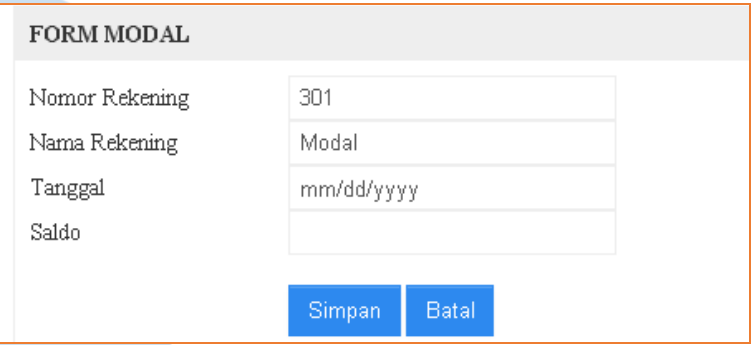

\section{Gambar 14. Form Modal}

Form modal digunakan untuk memasukkan data modal yang terdiri dari nomor rekening, nama rekening, tanggal, dan saldo.

\section{Form Pembelian}

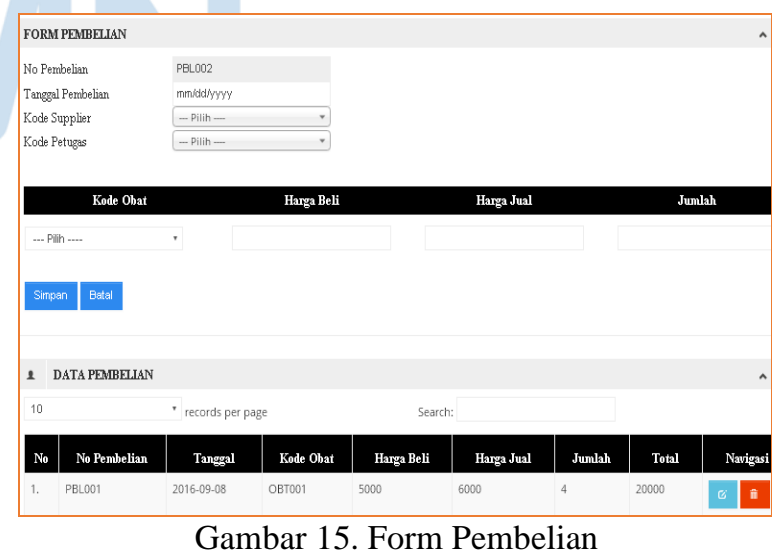

Form pembelian digunakan untuk memasukkan data pembelian yang terdiri dari nomor pembelian, tanggal pembelian, kode supplier, kode petugas, kode obat, harga beli, harga jual, dan jumlah. Dibawah form pembelian terdapat daftar data pembelian yang digunakan untuk menampung data yang akan disimpan. Selain disimpan ke dalam daftar data pembelian, data transaksi pembelian juga tersimpan secara otomatis ke dalam daftar data jurnal. 


\section{Form Penjualan}

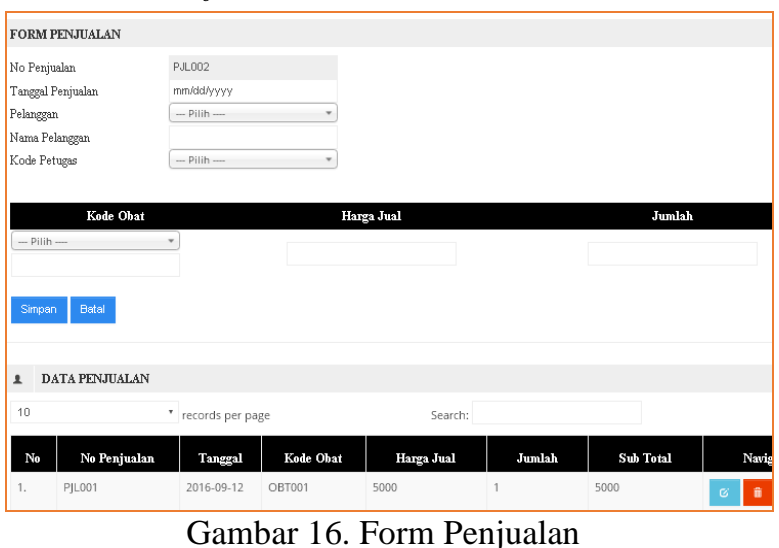

Form penjualan digunakan untuk memasukkan data penjualan yang terdiri dari nomor penjualan, tanggal penjualan, pelanggan (No RM), nama pelanggan, kode petugas, kode obat, harga jual, dan jumlah. Dibawah form penjualan terdapat daftar data penjualan yang digunakan untuk menampung data yang akan disimpan. Selain disimpan ke dalam daftar data penjualan, data transaksi penjualan juga tersimpan secara otomatis ke dalam daftar data jurnal.

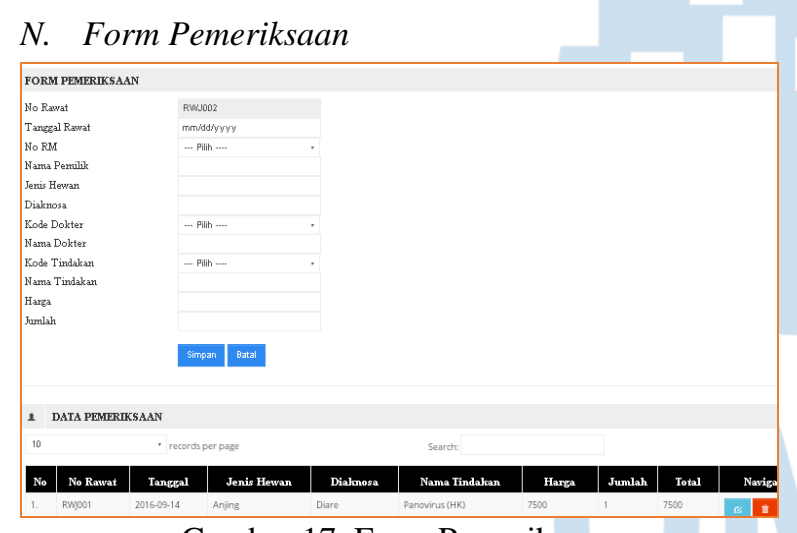

Gambar 17. Form Pemeriksaan

Form pemeriksaan digunakan untuk memasukkan data pemeriksaan yang terdiri dari nomor rawat, tanggal rawat, nomor rekam medis (No RM), nama pemilik, jenis hewan, diaknosa, kode dokter, nama dokter, kode tindakan, nama tindakan, harga, dan jumlah. Dibawah form pemeriksaan terdapat daftar data pemeriksaan yang digunakan untuk menampung data yang akan disimpan. Selain disimpan ke dalam daftar data pemeriksaan, data transaksi pemeriksaan juga tersimpan secara otomatis ke dalam daftar data jurnal.

\section{O. Laporan Dokter}

\begin{tabular}{|c|c|c|c|c|}
\hline \multicolumn{5}{|r|}{$\begin{array}{l}\text { KLINIK HEWAN XZY SEMARANC } \\
\text { PROPINSI JAWA TENGAH }\end{array}$} \\
\hline & Kode Dokter & Nama Dokter & TTL & Alamat \\
\hline 1 & DTR001 & Dth. Heri Gunawan Wribisono & Semarang 1975-09-06 & Semarang \\
\hline 2 & DTR002 & Dth Assa Nomalia & Magelang 1985.09.15 & Magelang \\
\hline \multicolumn{5}{|c|}{ Jumlah Data : 2} \\
\hline
\end{tabular}

Gambar 18. Laporan Dokter
Laporan dokter digunakan untuk menampilkan data dokter yang terdiri dari kode dokter, nama dokter, tempat tanggal lahir, dan alamat.

\section{P. Laporan Data Obat}

\begin{tabular}{|c|c|c|c|c|}
\hline \multicolumn{3}{|c|}{ LAPORAN DATA OBAT } & \multicolumn{2}{|c|}{$\begin{array}{l}\text { KLINIK HEWAN XZY SEMARANG } \\
\text { PROPINSI JAWA TENGAH }\end{array}$} \\
\hline No & Kode Obat & Nama Obat & Stok & Keterangan \\
\hline 1 & OBT001 & Kaloxy & 21 & Anttbiotivk \\
\hline 2 & OBT002 & Sulfa Strong & 59 & Obat Diare \\
\hline 3 & OBT003 & Ivomec & 50 & Obat Kulit \\
\hline 4 & OBT004 & Gusanex $13 \mathrm{Oz}$ & 50 & Obat Untuk Luka Kening \\
\hline 5 & OBTOOS & Biosalamin & 50 & Vitamin Setamina \\
\hline $\begin{array}{ll}6 & 6 \\
\end{array}$ & OBT006 & Biosan TP & 50 & Vitamin \\
\hline 7 & OBT007 & Haemathopan B - 12 & $s 1$ & $\begin{array}{l}\text { Supleman Daya Tahan } \\
\text { Tubuh }\end{array}$ \\
\hline 8 & OBT008 & Vit B -Plex & so & Vitamin \\
\hline 9 & OBT009 & Vit B -Komplex & so & Vitamin \\
\hline Juml & lah Data : 9 & & & \\
\hline
\end{tabular}

Gambar 19. Laporan Data Obat

Laporan data obat digunakan untuk menampilkan data obat yang terdiri dari kode obat, nama obat, stok dan keterangan.

\section{Q. Laporan Data Pasien}

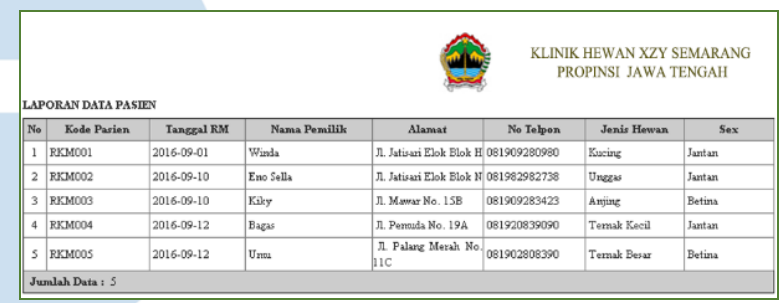

Gambar 20. Laporan Data Pasien

Laporan data pasien digunakan untuk menampilkan data pasien yang terdiri dari kode pasien, tanggal RM, nama pemilik, alamat, no telepon, jenis hewan, dan sex.

\section{R. Laporan Data Supplier}

\begin{tabular}{||c|l|l|l|l||}
\hline \multicolumn{5}{||l||}{} \\
LAPORAN DATA SUPPLIER \\
\hline No & \multicolumn{1}{|c|}{ Kode Supplier } & \multicolumn{1}{|c||}{ Nama Supplier } & \multicolumn{1}{|c|}{ Alamat } & No Telpon \\
\hline 1 & SPL001 & Wiwin & Semarang & 8509090 \\
\hline 2 & SPL002 & Dewi & Unggaran & 8502890 \\
\hline 3 & SPL003 & Suci & Semarang & 8502980 \\
\hline Jumlah Data : 3 & & & \\
\hline \hline
\end{tabular}

Gambar 21. Laporan Data Supplier

Laporan data supplier digunakan untuk menampilkan data supplier yang terdiri dari kode supplier, nama supplier, alamat, dan no telepon. 
S. Laporan Data Pembelian Obat

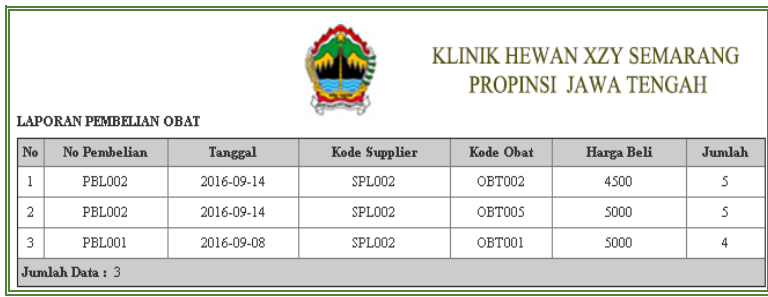

Gambar 22. Laporan Data Pembelian

Laporan data pembelian digunakan untuk menampilkan data pembelian obat. Data yang ditampilkan berupa data no pembelian, tanggal, kode supplier, kode obat, harga beli, dan jumlah.

\section{T. Laporan Data Penjualan Obat}

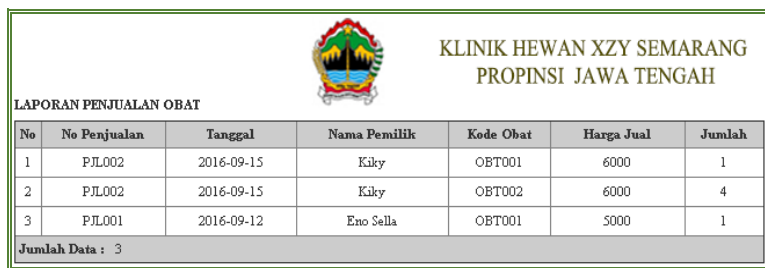

Gambar 23. Laporan Data Penjualan Obat

Laporan data penjualan obat digunakan untuk menampilkan data penjualan obat, yang terdiri dari no penjualan, tanggal, nama pemilik, kode obat, harga jual, dan jumlah.

\section{U. Laporan Data Pemeriksaan}

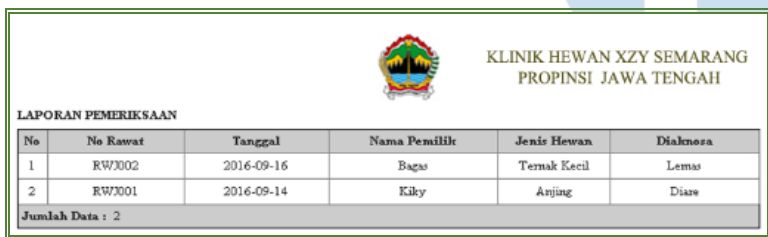

Gambar 24. Laporan Data Pemeriksaan

Laporan data pemeriksaan digunakan untuk menampilkan data pemeriksaan yang terdiri dari no rawat, tanggal, nama pemilih, jenis hewan, dan diagnosa.

\section{Laporan Data Jurnal Umum}

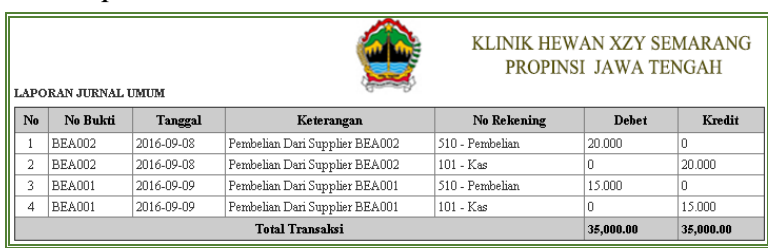

Gambar 25. Laporan Data Jurnal Umum

Laporan data jurnal umum digunakan untuk menampilkan data jurnal umum yang terdiri dari data nobukti, tanggal, keterangan, no rekening, debet, dan kredit.

\section{W. Laporan Data Buku Besar}

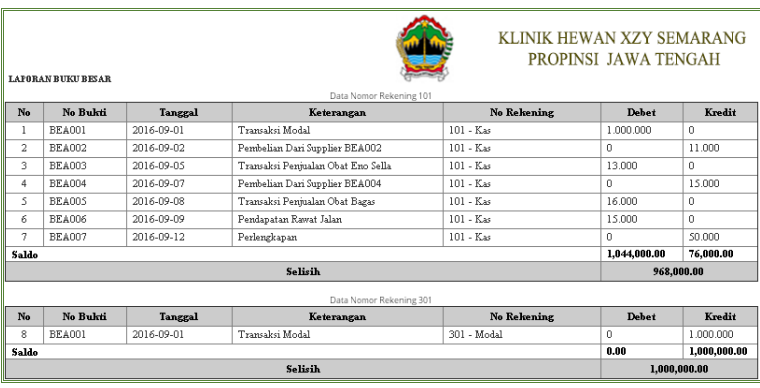

Gambar 26. Laporan Data Buku Besar

Laporan buku besar digunakan untuk menampilkan data buku besar yang terdiri dari data nobukti, tanggal, keterangan, no rekening, debet, dan kredit.

\section{Laporan Data Laba Rugi}

\begin{tabular}{|c|c|c|}
\hline & iin) & $\begin{array}{l}\text { KLINIK HEWAN XZY SEMARANG } \\
\text { PROPINSI JAWA TENGAH }\end{array}$ \\
\hline No & Pendapatan & Saldo \\
\hline 1 & 401 - Pendapatan & 15000 \\
\hline 2 & 410 - Penjualan & 29000 \\
\hline \multicolumn{2}{|r|}{ Total Saldo } & $44,000.00$ \\
\hline No & \multirow[b]{2}{*}{510 - Pembelian } & Saldo \\
\hline 3 & & 26000 \\
\hline \multicolumn{2}{|r|}{ Total Saldo } & $26,000.00$ \\
\hline Lapora & n Laba Rugi = 18,000.00 & \\
\hline
\end{tabular}

\section{Gambar 27. Laporan Data Laba Rugi}

Laporan laba rugi digunakan untuk menampilkan data laba rugi, data yang ditampilkan terdiri dari no rekening, nama rekening dan saldo. Hasil laporan laba rugi didapat dari hasil pendapat dalam satu periode tertentu dikurangi dengan biaya pengeluaran. Jika dalam satu periode tertentu hasil pendapatan lebih besar dari pengeluaran maka dikatakan menerima laba.

\section{Y. Laporan Data Pendapatan}

\begin{tabular}{||}
\hline \multicolumn{3}{|l||}{$\begin{array}{l}\text { KLINIK HEWAN XZY SEMARANG } \\
\text { PROPINSI JAWA TENGAH }\end{array}$} \\
LAPORAN PENDAPATAN \\
\begin{tabular}{|c|c|c|c||}
\hline No & Tanggal & Uraian Rincian Objek & Saldo \\
\hline 1 & $2016-09-05$ & 410 - Penjualan & 13.000 \\
\hline 2 & $2016-09-08$ & 410 - Penjualan & 16.000 \\
\hline 3 & $2016-09-09$ & 401 - Pendapatan & 15.000 \\
\hline & Total Saldo & $\mathbf{4 4 , 0 0 0 . 0 0}$ \\
\hline
\end{tabular}
\end{tabular}

Gambar 28. Laporan Data Pendapatan

Laporan data pendapan digunakan untuk menampilkan data pendapatan yang terdiri dari data tanggal, uraian pendapatan, dan saldo. 
Z. Laporan Data Net Profit Margin (NPM)

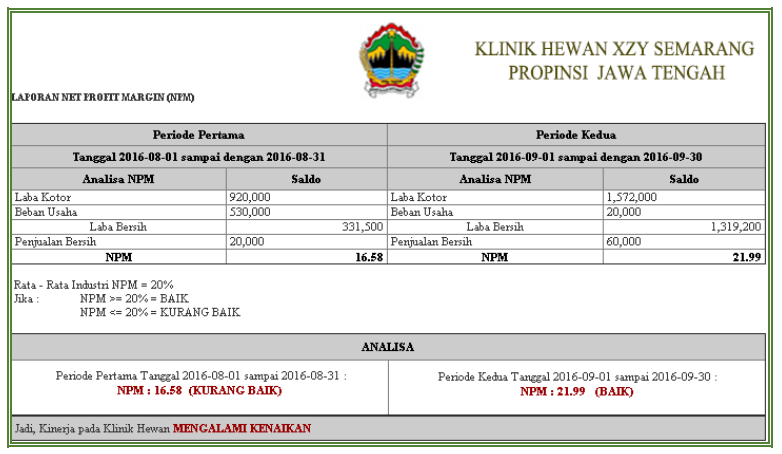

Gambar 29. Laporan Data NPM

Laporan data net profit margin digunakan untuk menampilkan laporan keuangan NPM. Bentuk rumus NPM adalah Laba Bersih dibagi Penjualan Bersih. Dari klasifikasi rata-rata industri NPM 20\%. Jika NPM $>=20 \%$ maka tergolong baik. Jika NPM $<=20 \%$ maka tergolong kurang baik.

Hasil analisa pada periode tanggal 01-08-2016 sampai 31-08-2016 hasil NPM sebesar 16.58 (kurang baik). Pada periode tanggal 01-09-2016 sampai 3009-2016 nilai NPM sebesar 21.99 (baik), maka terdapat kenaikan nilai NPM pada kilinik hewan XYZ.

\section{AA. Laporan Data Return On Asset (ROA)}

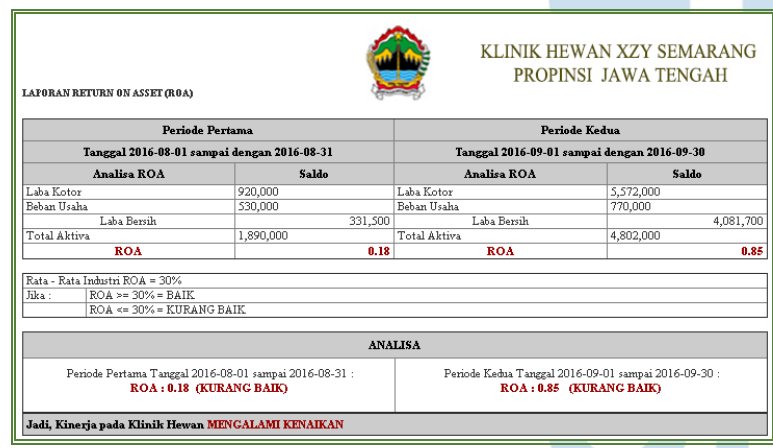

Gambar 30. Laporan Data ROA

Laporan data return on assest digunakan untuk menampilkan laporan keuangan ROA. Bentuk rumus ROA adalah laba bersih dibagi total aktiva. Untuk klasifikasi ROA memiliki standart jika nilai ROA $>=30 \%$ maka kategori baik, jika $<=30 \%$ kategori kurang baik. Dari hasil analisa pada gambar diatas pada periode 01-08-2016 sampai 30-08-2016 nilai ROA sebesar 0.18 sehingga kategori kurang baik.

Pada periode 01-09-2016 sampai 30-09-2016 nilai ROA sebesar 0.85 kategori kurang baik.

\section{SIMPULAN DAN SARAN}

Dari pemaparan, maka dapat diambil kesimpulan sebagai berikut :
1. Pengelolaan data keuangan pada klinik hewan xyz yang sebelumnya masih bersifat tunggal, sehingga mengalami kesulitan dalam penyampaian informasi, data tidak dapat diakses secara bersamaan, penyusunan data juga belum tersusun dengan baik, dan juga belum adanya penilaian kinerja keuangan pada klinik hewan XYZ tersebut. Sehingga sistem yang digunakan pada klinik hewan belum efektif.

Dari permasalahan tersebut mampu dibuatkan aplikasi sistem informasi klinik hewan untuk meningkatkan kinerja keuangan dengan menggunakan metode rasio profitabilitas dengan menggunakan bahasa pemrograman php dan MySQL sebagai databases-nya. Sehingga memberikan manfaat bagi klinik hewan xyz seperti memberikan kemudahan dalam mengevaluasi kinerja keuangannya, aplikasi dapat diakses secara bersamaan, dan memberikan kemudahan dalam penyediaan perlengkapan dan peralatan yang dibutuhkan.

2. Hasil penilaian terhadap produk dari ahli pakar adalah sebagai berikut :

Tabel 15 Hasil Penilaian Rancang Desain Program

\begin{tabular}{|c|c|c|c|c|c|}
\hline No & INDIKATOR & 1 & 2 & 3 & 4 \\
\hline 1 & $\begin{array}{l}\text { Apakah rancang desain DFD } \\
\text { (Data Flow Diagram) sudah } \\
\text { tepat? }\end{array}$ & & & & $\sqrt{ }$ \\
\hline 2 & $\begin{array}{lcr}\text { Apakah } \quad \text { rancang } & \text { desain } \\
\text { antarmuka (Interface) } & \text { untuk } \\
\text { sistem sudah tepat? } & \\
\end{array}$ & & & $\sqrt{ }$ & \\
\hline 3 & $\begin{array}{l}\text { Apakah rancang desain } \\
\text { normalisasi data sudah tepat? }\end{array}$ & & & $\sqrt{ }$ & \\
\hline 4 & $\begin{array}{l}\text { Apakah rancang desain ERD } \\
\text { (Entitiy Relational Diagram ) } \\
\text { sudah tepat? }\end{array}$ & & & $\sqrt{ }$ & \\
\hline 5 & $\begin{array}{l}\text { Apakah rancang desain struktur } \\
\text { tabel basis data sudah tepat? }\end{array}$ & & & $\sqrt{ }$ & \\
\hline 6 & $\begin{array}{l}\text { Apakah rancang desain input } \\
\text { program sudah tepat? }\end{array}$ & & & $\sqrt{ }$ & \\
\hline 7 & $\begin{array}{l}\text { Apakah rancang desain output } \\
\text { program sudah tepat? }\end{array}$ & & & $\sqrt{ }$ & \\
\hline 8 & $\begin{array}{llr}\text { Apakah rancang } & \text { desain } \\
\text { tampilan laporan } & \text { program } \\
\text { sudah tepat? } & \end{array}$ & & & $\sqrt{ }$ & \\
\hline 9 & $\begin{array}{l}\text { Apakah rancang desain menu - } \\
\text { menu pada program sudah } \\
\text { sesuai kebutuhan? }\end{array}$ & & & $\sqrt{ }$ & \\
\hline 10 & $\begin{array}{l}\text { Apakah rancang desain } \\
\text { program mudah dipahami oleh } \\
\text { pengguna? }\end{array}$ & & & $\sqrt{ }$ & \\
\hline & JUMLAH SKOR & \multicolumn{4}{|c|}{31} \\
\hline & TOTAL JUMLAH SKOR & \multicolumn{4}{|c|}{31} \\
\hline
\end{tabular}


Tabel 16 Skala Kriteria Validasi

\begin{tabular}{|c|c|}
\hline Nilai & Kriteria Kevalidan \\
\hline $3,26-4,00$ & Sangat Valid \\
\hline $2,51-3,25$ & Valid (Baik) \\
\hline $1,76-2,50$ & Kurang Valid (Revisi) \\
\hline $1,00-1,75$ & Tidak Valid (Revisi total) \\
\hline
\end{tabular}

Tabel 17 Hasil Pengisian Angket User

\begin{tabular}{|c|c|c|c|c|}
\hline NO & INDIKATOR & $\begin{array}{c}\text { User } \\
1\end{array}$ & $\begin{array}{c}\text { User } \\
2\end{array}$ & $\begin{array}{c}\text { User } \\
3\end{array}$ \\
\hline 1 & $\begin{array}{l}\text { Kenyamanan } \\
\text { melihat tampilan } \\
\text { muka dan lembar - } \\
\text { lembar berikutnya }\end{array}$ & 3 & 4 & 3 \\
\hline 2 & $\begin{array}{l}\text { Adakah kemudahan } \\
\text { melakukan input } \\
\text { data keuangan }\end{array}$ & 4 & 3 & 3 \\
\hline 3 & $\begin{array}{l}\text { Apakah informasi - } \\
\text { informasi tampilan } \\
\text { memberikan } \\
\text { kemudahan } \\
\text { pengguna }\end{array}$ & 3 & 3 & 4 \\
\hline 4 & $\begin{array}{lr}\text { Apakah pengguna } \\
\text { merasa } & \text { senang } \\
\text { mengakses } & \text { karena } \\
\text { cepat memperoleh } \\
\text { informasi }\end{array}$ & 3 & 3 & 4 \\
\hline 5 & $\begin{array}{l}\text { Apakah pengguna } \\
\text { merasa puas karena } \\
\text { informasi yang ada } \\
\text { sesuai kebutuhan } \\
\text { pengguna }\end{array}$ & 3 & 4 & 3 \\
\hline 6 & $\begin{array}{l}\text { Pengguna akan } \\
\text { terus mengakses } \\
\text { karena } \\
\text { dimungkinkan } \\
\text { proses cepat }\end{array}$ & 3 & 4 & 3 \\
\hline 7 & $\begin{array}{ll}\text { Apakah } & \text { output } \\
\text { sudah } & \text { sesuai } \\
\text { dengan harapan? }\end{array}$ & 4 & 4 & 3 \\
\hline 8 & $\begin{array}{l}\text { Apakah pengguna } \\
\text { merasa program ini } \\
\text { sudah menyajikan } \\
\text { laporan keuangan } \\
\text { yang } \\
\text { memperlihatkan } \\
\text { posisi a kinerja } \\
\text { keuangan }\end{array}$ & 3 & 3 & 3 \\
\hline 9 & $\begin{array}{l}\text { Apakah pengguna } \\
\text { merasakan } \\
\text { perubahan antara } \\
\text { sistem lama dengan } \\
\text { yang baru }\end{array}$ & 4 & 3 & 4 \\
\hline 10 & $\begin{array}{l}\text { Apakah hasil } \\
\text { pemilihan SIA ini } \\
\text { mempermudah } \\
\text { dalam pengambilan } \\
\text { keputusan }\end{array}$ & 4 & 3 & 4 \\
\hline \multicolumn{2}{|r|}{ JUMLAH SKOR } & 34 & 34 & 34 \\
\hline \multicolumn{2}{|r|}{$\begin{array}{c}\text { TOTAL JUMLAH } \\
\text { SKOR }\end{array}$} & \multicolumn{3}{|c|}{102} \\
\hline
\end{tabular}

Jumlah total nilai sebanyak 3 responden adalah 102, maka dapat dihitung rata-rata $=$ total Nilai responden/ jumlah rsponden $(102 / 3=34)$. Maka diperoleh nilai validasi dari responden sebagai berikut $34 / 10=3.4$

Dapat diambil kesimpulan bahwa nilai yang diperoleh berada diantara 2.51 sampai 3.25 kategori valid atau baik. Dari hasil penilaian validator produk dari user atau pengguna dapat disimpulkan bahwa nilai yang diperoleh 3.4 berada diantara 3.26 sampai 4.00 kategori sangat valid.

Setelah pembuatan sistem informasi klinik hewan untuk meningkatkan kinerja keuangan ini dilakukan, ada beberapa saran yang perlu dikembangkan pada penelitian selanjutnya, yaitu :

1. Pada sistem informasi klinik hewan untuk meningkatkan kinerja keuangan dengan metode rasio profitabilitas keuangan masih bersifat offline. Diharapkan untuk pengembangan selanjutnya memberikan sistem informasi klinik hewan yang dapat diakses secara online.

2. Pada sistem informasi klinik hewan ini hanya menerapkan metode rasio profitabilitas. Diharapkan untuk pengembangan selanjutnya memberikan sistem informasi akuntansi penilaian kinerja keuangan dengan menerapkan metode rasio keuangan yang lebih lengkap dengan cara menambahkan komponen lain yang bisa dimasukkan ke dalam produk sehingga laporan kinerja keuangan yang dihasilkan lebih lengkap.

\section{DAFTAR PUSTAKA}

Arfan Ikhsan Lubis ," Akuntansi Keperilakuan: Akuntansi Multiparadigma" 2018, Salemba Empat Jakarta.

Dahlia MO, Mahdiana, "Penggabungan Metode Analytical Hierarchy Process Dan Multi-Objective Optimization On The Basis Of Ratio Analysis Untuk Pemilihan Pegawai Terbaik Pada Klinik Yadika Petukangan,” Jurnal IDEALIS, Vol 3 No.1 , 2020, hal 123-132.

[3] Dewi, K.Soedarsono, Dkk, Sistem Manajemen Komunikasi (Teori, Model, dan Aplikasi) Simbiosa Rekatama Media. 2020

[4] Isti Aning Ika Haryani," Rancang Bangun Sistem Informasi Keuangan Menggunakan Metode Analisis Rasio keuangan Berbasis Website," JMI, Vol 10, No.1, 2019, hal 49-57.

[5] James A Brien, Geoge M. Marakas "Pengantar Sistem Informasi" Salemba Empat, 2017 Gudang Penerbit.

[6] Leny Mirta Sari, Achmad Arwan, Djoko Pramono," Pengembangan Sistem Informasi Rekam Medis Hewan dan Rekapitulasi Transaksi Berbasis Web (Studi Kasus : Klinik Hewan House Of Pet Malang)," JPTIIK Vol 4, No.11, 2020, hal 3905-3912.

[7] Nadia Pranata, Tiara Nur Safitri," Sistem Pendukung Keputusan Menentukan Kelanjutan Dan Kinerja Keuangan Pada Usaha Produksi Gas Menggunakan Metode Rasio Likuiditas,” JSON, Vol 2 No.2, 2020, hal 206-211.

[8] Nusa Putra, 2012,” Research dan Development/Penelitian dan Pengembangan : Suatu Pengantar/Nusa Putra," Raja Grafindo : Jakarta. 
